\section{Watermelon Transplant Age: Influence on Fruit Yield}

\author{
Charles S. Vavrina ${ }^{1}$ \\ Horticultural Sciences Department, Southwest Florida Research and Education \\ Center, P.O. Drawer 5127, Immokalee, FL 33934
}

Stephen Olson ${ }^{2}$

Horticultural Sciences Department, North Florida Research and Education

Center, Route 3, Box 4370, Quincy, FL 32351

\section{J.A. Cornell ${ }^{3}$ \\ Department of Statistics, Institute of Food and Agricultural Sciences, University of Florida, Gainesville, FL 32611}

Additional index words. cell size, Citrullus lanatus, modular trays

\begin{abstract}
Total fruit yield of watermelon [Citrullus lanatus (Thunb.) Matsum. and Nakai] in Florida field tests was unaffected by transplant age $(3,4$, or 5 weeks from seeding) or modular cell size $\left(18.8,30.7\right.$, or $\left.60.5 \mathrm{~cm}^{3}\right)$, but was affected by trial year. A further study revealed that early and total fruit yields at two field sites were unaffected by transplant age, ranging from 3 to 13 weeks, when grown in the same modular cell size $\left(34 \mathrm{~cm}^{3}\right)$, but were affected by field trial site. We conclude that transplant age or modular cell size is of little importance relative to post-transplanting conditions (site or year) in influencing watermelon fruit yield.
\end{abstract}

When growers alter planting schedules, they often ask that transplant delivery be delayed. Extension personnel, however, suggest that the "ideal" watermelon transplant age is 4 weeks (Lorenz and Maynard, 1988). When transplants are abundant, growers may reject older transplants; when they are in short supply, growers often accept all transplants regardless of plant age or condition.

Transplant age studies have produced varied results: no effect on tomato (Lycopersicon esculentum Mill.) fruit yield (Leskovar and Cantliffe, 1991); increased early and total tomato fruit yield (Marr and Jirak, 1990), increased early and total eggplant (Solarium melongena L.) yield (Harmon et al., 1991); increased early yield but no effect on total pepper (Capsicum annuum L.) fruit yield (Weston and Zandstra, 1988); inconsistent increases in early and total cole crop yield (Jones et al., 1991); and no effect on broccoli (Brassica oleracea L. Botrytis Group) head weight or diameter (Lament, 1992).

Hall (1989) obtained a higher total weight of watermelon fruit from transplants grown in $39.5-\mathrm{cm}^{3}$ ratherthanin $18.8-\mathrm{cm}^{3}$ modular cells. Weston and Zandstra (1986) reported lower early yields, but similar total yields, from tomato transplants grown in relatively small modular cells. Marsh and Paul (1988) found

Received for publication 17 June 1992. Accepted for publication $26 \mathrm{Feb}$. 1993. Florida Agricultural Experiment Station Journal series no. R02489. The. cost of publishing this paper was defrayed in part by the payment of page charges. Under postal regulations, this paper therefore must be hereby marked advertisement solely to indicate this fact.

'Assistant Professor,

${ }^{2}$ Associate Professor.

${ }^{3}$ Professor. cabbage transplants grown in linger cells produced heavier, but not larger, heads.

To our knowledge, no data exist on the effects of cucurbit transplant age or on the interaction of age and modular cell size. This research was conducted to determine the effects of transplant age and modular cell size on watermelon fruit yield.

Modular cell volume and transplant age. 'Charleston Grey' watermelon seeds were sowninMetro Mix 220 (Grace Sierra, Milpitas, Calif.) contained in inverted pyramid cells of expanded polystyrene flats (Todd planter flats; Speedling Corp., Plant City, Fla.). Three cell sizes were tested: $18.8 \mathrm{~cm}^{3}(2.5 \times 2.5 \times 7.6 \mathrm{~cm}$ deep), $30.7 \mathrm{~cm}^{3}(3.8 \times 3.8 \times 6.4 \mathrm{~cm}$ deep $)$, and $65.5 \mathrm{~cm}^{3}(5.1 \times 5.1 \times 7.6 \mathrm{~cm}$ deep $)$. The transplants were raised under natural light in a greenhouse set to cool at $32 \mathrm{C}$ and heat at $16 \mathrm{C}$. The transplants (one per cell) were fertilized daily with $200 \mathrm{mg}$ N/liter from $15 \mathrm{~N}-3 \mathrm{P}-12 \mathrm{~K}$ (15-7-14; Peters Fertilizer, Fogelsville, Pa.). Transplants that were 3,4 , or 5 weeks old were transplanted on 28 Mar. 1984,28 Mar. 1985, and 27 Mar. 1986 into Orangeburg loamy fine sand (fine-loamy, siliceous, thermic Typic Kandiudult) at the North Florida Research and Education Center in Quincy. The land had not been in watermelon production for 10 years.

Each plot contained 12 transplants $1.0 \mathrm{~m}$ apart in a single row down the center of a raised bed. Rows were $3 \mathrm{~m}$ apart. Plots had received preplant applications of dolomitic limestone at recommended rates and (in $\mathrm{kg} \cdot \mathrm{ha}^{-1}$ ) $157 \mathrm{~N}-$ $70 \mathrm{P}-100 \mathrm{~K}$ in 1984 , and $134 \mathrm{~N}-36 \mathrm{P}-32 \mathrm{~K}$ in 1985 and 1986. Black polyethylene (0.032 $\mathrm{mm}$ ) covered the nonfumigated, $90-\mathrm{cm}$-wide beds. Overhead irrigation and recommended pesticides (Maynard, 1990) were applied as needed.
The 3 (transplant age) $\mathbf{x} 3$ (cell size) factorial was arranged in a randomized complete block design with four replications in each year. Fruit were harvested three times each year. Fruit $<6.8 \mathrm{~kg}$ were excluded from determinations of total marketable fruit yield (in tonne per hectare) and mean fruit weight.

Although a year effect was apparent, neither transplant age nor modular cell volume affected total yield or mean fruit weight (Table 1). The lack of cell size influence contradicted the results of Hall's (1989) 1-year study in which 'Charleston Grey' 4-week-old transplants grown in $39.5-\mathrm{cm}^{3}$ cells yielded more than those from $18.8-\mathrm{cm} 3$ cells. Since cell size exerted no effect on fruit yield, the next series of studies examined the effects on fruit yield of a wider range of transplant age in modular cells of the same volume.

Transplant age and site. 'Crimson Sweet' watermelon seeds were sown biweekly into Heco Plug Mix (Southern Importers, Greensboro,N. C.) contained in $34-\mathrm{cm}^{3}$ hemispherical (5 $\mathrm{cm}$ in diameter) cells to achieve transplants that were $3,5,7,9,11$, or 13 weeks old at transplant time. The transplants were raised in a commercial greenhouse (Johnny Johnson's Greenhouses, Immokalee, Fla.) under natural light and temperature regimes (November to February temperature range: $23-26 \mathrm{C}$ days and $10-15 \mathrm{C}$ nights), and they received $200 \mathrm{mg} \mathrm{N} /$ liter from 20N4P-17K (Peter's 20-10-20) daily.

The transplants were planted on 9 Feb. 1990 at Immokalee and Fort Myers in Immokalee fine sand (sandy, siliceous, hypothermic, Arenic Haplaquod). At Immokalee, $56 \mathrm{~N}-67 \mathrm{P}-78 \mathrm{~K}$ was broadcast at $1120 \mathrm{~kg} \cdot \mathrm{ha}^{-1}$. Beds were fumigated with 98 methyl bromide :2 trichloronitromethane (chloropicrin) (v/v) at $201 \mathrm{~kg} \cdot \mathrm{ha}^{-1}$; we simultaneously applied

Table 1. Influence of year, transplant age, and transplant cell volume on weight of 'Charleston Grey' watermelon.

\begin{tabular}{|c|c|c|}
\hline Factor & $\begin{array}{c}\text { Total } \\
\text { fruit yield } \\
\left(\mathrm{t} \cdot \mathrm{ha}^{-1}\right)\end{array}$ & $\begin{array}{c}\text { Mean } \\
\text { fruit wt } \\
\text { (kg/fruit) }\end{array}$ \\
\hline \multicolumn{3}{|l|}{ Year } \\
\hline 1984 & $41.6 b^{2}$ & $8.3 \mathrm{c}$ \\
\hline 1985 & $67.8 \mathrm{a}$ & $11.2 \mathrm{a}$ \\
\hline 1986 & $41.9 b$ & $9.6 \mathrm{~b}$ \\
\hline \multicolumn{3}{|l|}{ Transplant age (weeks) } \\
\hline 3 & 49.8 & 9.7 \\
\hline 4 & 49.7 & 9.6 \\
\hline 5 & 51.7 & 9.9 \\
\hline \multicolumn{3}{|l|}{ Cell volume $\left(\mathrm{cm}^{3}\right)$} \\
\hline 18.8 & 49.5 & 9.8 \\
\hline 30.7 & 49.7 & 9.7 \\
\hline 65.5 & 52.0 & 9.7 \\
\hline \multicolumn{3}{|l|}{ F test significance } \\
\hline Year $\quad(Y r)$ & $* *$ & $* *$ \\
\hline Transplant age (Ta) & NS & NS \\
\hline Cell volume $(\mathrm{Cv})$ & Ns & NS \\
\hline $\mathrm{Yr} \times \mathrm{Ta}$ & NS & NS \\
\hline $\mathrm{Yr} \times \mathrm{Cv}$ & NS & NS \\
\hline $\mathrm{Ta} \times \mathrm{Cv}$ & NS & NS \\
\hline $\mathrm{Yr} \times \mathrm{Ta} \times \mathrm{Cv}$ & NS & NS \\
\hline
\end{tabular}

${ }^{2}$ Mean separation within columns at $P 0.05$ according to Duncan's multiple range test.

${ }^{\mathrm{Ns},{ }^{* *}}$ Nonsignificant or significant at $P \leq 0.01$, respectively. 
Table 2. Early and total fruit yields of 'Crimson Sweet' watermelon as influenced by transplant age and site.

\begin{tabular}{|c|c|c|c|c|}
\hline \multirow[b]{2}{*}{$\begin{array}{l}\text { Transplant } \\
\text { age (wks) }\end{array}$} & \multicolumn{2}{|c|}{ Early yield } & \multicolumn{2}{|c|}{ Total yield } \\
\hline & $\left(\mathrm{t} \cdot \mathrm{ha}^{-1}\right)$ & $\begin{array}{c}\text { (no. fruit/ha) } \\
1000 \mathrm{~s}\end{array}$ & $\left(t \cdot h a^{-1}\right)$ & $\begin{array}{c}\text { (no. fruit/ha) } \\
1000 \mathrm{~s}\end{array}$ \\
\hline \multicolumn{5}{|c|}{ Fort Myers } \\
\hline 3 & 39.5 & 3.96 & 73.1 & 7.23 \\
\hline 5 & 45.4 & 4.75 & 79.3 & 7.80 \\
\hline 7 & 35.6 & 3.39 & 78.9 & 7.91 \\
\hline 9 & 42.4 & 4.29 & 69.2 & 7.23 \\
\hline 11 & 25.7 & 2.71 & 54.6 & 5.76 \\
\hline 13 & 41.6 & 3.96 & 75.1 & 7.35 \\
\hline \multicolumn{5}{|c|}{ Immokalee } \\
\hline 3 & 87.1 & 8.90 & 124.1 & 13.3 \\
\hline 5 & 94.3 & 9.40 & 126.3 & 13.5 \\
\hline 7 & 84.4 & 8.54 & 114.9 & 12.6 \\
\hline 9 & 86.9 & 8.97 & 122.9 & 13.7 \\
\hline 11 & 81.7 & 8.82 & 116.4 & 13.1 \\
\hline 13 & 84.6 & 8.68 & 116.6 & 12.5 \\
\hline \multicolumn{5}{|l|}{ F test significance } \\
\hline Site (S) & $*$ & $*$ & $*$ & $*$ \\
\hline Transplant age (Ta & NS & NS & NS & NS \\
\hline $\mathrm{S} \times \mathrm{Ta}$ & NS & NS & NS & NS \\
\hline
\end{tabular}

$\overline{\text { NS." }}$ Nonsignificant or significant at $P \leq 0.05$, respectively.

$153 \mathrm{~N}-0 \mathrm{P}-201 \mathrm{~K}$ at $806 \mathrm{~kg} \cdot \mathrm{ha}^{-1}$ in two narrow bands on the top of the bed $25 \mathrm{~cm}$ to either side of the bed center. The beds were then sealed with 0.032 -mm-thick black polyethylene plastic. The raised beds $(20 \mathrm{~cm}$ high $\times 91 \mathrm{~cm}$ wide on $3.7-\mathrm{m}$ centers) were irrigated by subsurface seepage.

At the Fort Myers site, a 10-year-old bahiagrass (Paspalum notatum Flugge.) pasture prepared several months in advance by repeated discing, received (in $\mathrm{kg} \cdot \mathrm{ha}^{-1}$ ) $112 \mathrm{~N}$ 45P-90K. The 61-cm-high $\times 122$-cm-wide beds were neither fumigated nor covered with plastic mulch, but received subsurface seepage irrigation.

The design was a randomized complete block consisting of eight blocks, with four blocks at each site. Each plot was a 6.4-m-long bed containing a single row of seven transplants $91 \mathrm{~cm}$ apart. Plants that did not survive transplanting were replaced within 10 days with appropriately aged plants. Pesticides were applied as needed, according to the Florida Cooperative Extension Pest Control Program (Maynard, 1990).

Fruit were harvested 27 Apr. and 4,15, and 25 May at Immokalee, and 3 and 17 May at Fort Myers. Fort Myers plots were only harvested twice due to cooperator harvesting error. We determined fresh weight and number of marketable fruit per hectare for early (first harvest only at Fort Myers, first two harvests at Immokalee) and total harvests.

The dry weight, leaf area, height, and number of nodes of transplants increased with increasing transplant age (data not shown). These results were in agreement with other observations for increasing transplant age on yield (Lament, 1992; Leskovar and Cantliffe, 1991). It seems that watermelon transplants physiologically synchronize fruit set and development in spite of chronological age. This synchronization may be heightened by Florida growing conditions, which are generally favorable. Weston and Zandstra ( 1988) showed than solanaceous transplants produced near the study site were more productive than those shipped long distances. Further work is required to test the interactive effects of watermelon transplant age with shipping distance or shipping conditions on field performance.

Our results indicated that watermelon transplants produced similar yields regardless of cell volume or transplant age. Yields, however, were affected by year and site. Thus, even with varied cultural practices or environments, watermelon transplants up to 13 weeks old have yields similar to 4 -week-old plants, which had been considered the ideal age for planting.

\section{Literature Cited}

(Leskovar and Cantliffe, 1991; Marsh and Paul, 1988; Weston and Zandstra, 1986). The percentage of plant death following transplanting was similar for all transplant ages.

Early and total fruit yields were influenced by site but not by transplant age or its interaction with site (Table 2). The higher yields at Immokalee than at Fort Myers maybe attributed to the black plastic mulch covering the beds at Immokalee. The tendency for springplanted plasticulture (mulch) watermelons to produce higher yields than watermelons grown on bare ground has been observed (Bhella, 1988). A delay of several weeks occurred before irrigation was properly implemented at Fort Myers. Although modest rainfall supported growth, this factor also may have contributed to the lower early yield at Fort Myers than at Immokalee, as we noticed an overall reduction in crop vigor. The higher early and total yields at Immokalee were the result of more fruit produced (Table 2), not heavier fruit.

The original 11 -week-old transplants failed before transplanting were replaced with transplants obtained from another commercial source. These replacement plants were grown in smaller cells $\left(25 \mathrm{~cm}^{3}\right)$, nutrient deficient, and flowering. They tended to produce lower yields than the original transplants at Fort Myers, but not at Immokalee.

Despite differences in transplant size at setting, transplant age had no effect on early or total yield (Table 2). While differences in both early and total yield resulting from transplant age differences in various crops have been reported (Harmon et al., 1991; Marr and Jirak, 1990), others have documented no age effect
Bhella, H.S. 1988. Effect of trickle irrigation and black mulch on growth, yield and mineral composition of watermelon. HortScience 23:123125.

Hall, M.R. 1989. Cell size of seedling containers influences early vine growth and yield of transplanted watermelon. HortScience 24:771-773.

Harmon, R., L.A. Weston, and R.T. Jones. 1991 Effect of root cell size and transplant age on Yield of transplanted eggplant. HortScience 26:689. (Abstr.)

Jones, R. T., L.A. Weston, and R. Harmon. 1991. Effect of root cell size and transplant age on cole crop yields. HortScience 26:688. (Abstr.)

Lamont, W.J. 1992. Transplant age has little effect on broccoli head weight and diameter. HortScience 27:848.

Leskovar, D.I. and D.J. Cantliffe. 1991. Growth and yield of tomato plants in response to age of transplants. J. Amer. Soc. Hort. Sci. 116:416 420

Lorenz, O.A. and D.N. Maynard (eds.). 1988. Knott's handbook for vegetable growers. 3rd ed. Wiley, New York.

Marr, C.W. and M. Jirak. 1990. Holding tomato transplants in plug trays. HortScience 25:173176.

Marsh, D.B. and K.B. Paul. 1988. Influence of container type and cell size on cabbage transplant development and field performance. HortScience 23:310-311.

Maynard, D. (cd.). 1990. Watermelon production guide for Florida. Univ. Florida, Coop. Ext. Bul. SP113.

Weston, L.A. and B. Zandstra. 1986. Effect of root container size and location of production on growth and yield of tomato transplants. J. Amer. Soc. Hort. Sci. 111:498-501.

Weston, L.A. and B. Zandstra. 1988. Effect of flat cell size, transplant age, and production site on growth and yield of pepper transplants. HortScience 23:709-711. 